\title{
Impacts of the peer-to-peer market on tourist accommodation on the Balearic Islands of Mallorca and Menorca
}

\author{
Beatriz Benítez-Aurioles \\ University of Malaga, Spain \\ bbaurioles@gmail.com
}

\begin{abstract}
Using the Balearic Islands of Mallorca and Menorca as case studies, this research identifies the patterns of development in the peer-to-peer market for tourist accommodation in the islands. Characteristics of this market include the predominance of the supply of entire homes and the concentration of demand in a few accommodations, as well as the remarkable unequal spatial distribution in the existing urban structure and the aggravation of problems related to seasonality. Nevertheless, the different degree of maturity of each market differs in the two cases. The results show hotel occupancy suffers from the intensification of tourist housing, independent of hotel category, or of the growth of demand in the peer-to-peer market, while tourism employment increases. These results suggest the impacts are evident beyond some threshold of tourism market development.
\end{abstract}

Keywords: Airbnb, Balearic Islands, Mallorca, Menorca, peer-to-peer markets, tourism

https://doi.org/10.24043/isj.108 • Received April 2019, accepted October 2019

(C) 2020-Institute of Island Studies, University of Prince Edward Island, Canada.

\section{Introduction}

Thanks to internet-based marketplaces, private buyers and sellers can trade a wide variety of goods and services (Einav, Farronato, \& Levin, 2016). Both sides of the online platforms have substantially reduced information, search, and transaction costs. One of them is Airbnb, a disruptive innovation that has allowed homeowners to offer a place to sleep to potential tourists from all over the world (Guttentag, 2015). The company was founded in 2008 and since then its growth has been exponential. According to Airbnb, its total supply of accommodation exceeds six million homes, covering more than 80,000 cities in virtually all countries (Airbnb, 2019); this figure is higher than the supply of the five largest hotel chains combined (Hartmans, 2017).

The peer-to-peer ( $\mathrm{p} 2 \mathrm{p})$ market for tourist accommodation has increased so much that its effects have been the topic of discussion for some years now, in the social, political, and academic spheres. Still, in spite of its relevance, there is limited research into the value it is causing in an island economy context. This article intends to cover that gap.

Therefore, the research question is: what is the impact of the $\mathrm{p} 2 \mathrm{p}$ market on island economies? We seek to determine whether Airbnb "is bad for hotels but good for tourism" (Oskam \& Boswijk, 2016) in islands. More concretely, taking as a reference the islands of 
Mallorca and Menorca, we examine the effects of the p2p market on hotel occupancy and employment.

This work is organized as follows: the next section provides a literature review, followed by the methodology and statistical sources utilized. Afterwards, the most important characteristics of the $\mathrm{p} 2 \mathrm{p}$ market for accommodation in the islands are highlighted. Next, the $\mathrm{p} 2 \mathrm{p}$ market's impacts on hotel occupancy and employment are quantified. Finally, a subsection is devoted to conclusions, implications, limitations, and future lines of research.

\section{Literature review}

A recent survey of tourism research on island destinations estimated that the number of references for 'tourism in island destination', between 1980 and 2017 in the SCOPUS database, represented only $0.2 \%$ of studies that only included the word 'island' (Parra-López \& Martínez-González, 2018). However, a reading of the titles of scholarly articles published in Island Studies Journal, since its beginning in 2006, shows that more than $10 \%$ refer to tourism in some way or another. Numerous academic contributions underscore the importance of productive activities related to tourism in island economies (Bojanic \& Lo, 2016; Figini \& Vici, 2010). Thus, for islands, the costs or benefits of tourism are of special importance (Dwyer \& Forsyth, 1993).

On the one hand, there seems to be a consensus that tourism promotes economic growth backed by empirical evidence. Therefore, with a few exceptions, the tourism-led growth hypothesis is validated (Brida, Cortes-Jimenez, \& Pulina, 2016). Research referencing islands has supported this hypothesis (Durbarry, 2004; Jackman, 2012; Katircioglu, 2010; Kim, Chen, \& Jang, 2006; Lee \& Chang, 2008; Narayan, Narayan, Prasad, \& Prasad, 2010; Parrilla, Font, \& Nadal, 2007), although a bi-causal relationship between tourism and growth has also been suggested (Katircioglu, 2009). It has been argued that tourism positively affects island economies through direct and indirect job creation and through investment in tourist projects that generate social profits for the local population (Seetanah, 2011). Other benefits are currency inflows (Archer, 1995), the tax contribution from tourism (Durbarry, 2002), or the improvement of infrastructure and services in Singapore (Khan, Seng, \& Cheong, 1990). Even the degree of economic resilience of the islands facing the most recent financial crisis has been related to tourist expenditure (Podhorodecka, 2018).

On the other hand, the costs of tourist development can also be more intense in islands. For example, according to Scheyvens and Momsen (2008), the growth of tourism in small island developing states is by no means synonymous with poverty reduction; in fact, in some cases it can entrench existing inequalities. Despite the large amount of economic activity created by tourism, it is noted that only a small part of the generated income stays in the destination (Pratt, 2015). Most frequently, emphasis is placed on the social and environmental costs of tourist development experienced by certain islands (Ayres, 2000; Chen, 2006; Fotiou, Buhalis, \& Vereczi, 2002; Ghina, 2003; Kokkranikal et al, 2003; Milne, 1992; Shareef \& McAleer, 2005; Sharpley, 2003; Teelucksingh \& Watson, 2013; Wilkinson, 1989). Problems associated to tourism seasonality in islands have deserved particular attention (Donatos \& Zairis, 1991). Actually, that is the classical pattern of tourism demand (Baum \& Lundtorp, 2001) and is especially marked for sun-and-beach destinations. Among the problems generated by this 
phenomenon is the human pressure on available resources, disproportionately present at certain times of the year, which has negative social, economic, and environmental consequences.

The recent expansion of the $\mathrm{p} 2 \mathrm{p}$ market for tourist accommodation represents an additional consideration in debates about the benefits and drawbacks of tourist expansion in islands. The interest of researchers for this phenomenon has generated a substantial number of contributions, all very diverse in terms of domains, methods, and scope (Belarmino \& Koh, 2020; Dann, Teubner, \& Weinhardt, 2019; Dolnicar, 2019; Guttentag, 2019). Previous analyses of Airbnb were focused, among other things, on finding out what motivates suppliers and demanders to participate in this market (Karlsson \& Dolnicar, 2016; So, Oh, \& Min, 2018); on its potential discriminatory effect against certain groups (Edelman et al, 2017; Kakar, Franco, Voelz, \& Wu, 2016); on the established reputation mechanisms (Fradkin, Grewal, Holtz, \& Pearson, 2015; Zervas, Proserpio, \& Byers, 2015); on the variables that may or may not determine price (Benítez-Aurioles, 2018a; Wang \& Nicolau, 2017); and on the repercussions that it has had on hotels (Heo, Blal, \& Choi, 2019; Zervas et al, 2017), employment (Fang, Ye, \& Law, 2016; Mao, Tian, \& Ye, 2018), and the housing market (Barron, Kung, \& Proserpio, 2018; Horn \& Merante, 2017).

Certain particular aspects of the $\mathrm{p} 2 \mathrm{p}$ market for tourist accommodation have used some islands as a reference. Campbell, McNair, Mackay, \& Perkins (2019) show the spatial distribution of supply in Airbnb accommodation in New Zealand. Camilleri and Neuhofer (2017) develop a theoretical framework of value co-creation and value co-destruction of guest-host social practices facilitated through Airbnb, analyzing guest reviews and posted host responses, in the context of Malta. Eugenio-Martin, Cazorla-Artiles, \& González-Martel (2019) study the determinants of Airbnb location and Airbnb's spatial distribution in the Canary Islands. Grimmer, Vorobjovas-Pinta, \& Massey (2019) study the regulatory problems in Tasmania. Johnson and Neuhofer (2017) make an exploration of value co-creation experiences in Jamaica. Malazizi, Alipour, \& Olya (2018) analyze risk perceptions of Airbnb hosts in Cyprus. Martín Martín et al (2018) underline the potential environmental costs in the Balearic Islands, and Xifilidou, Mangina, \& Karanikolas (2018) expose Airbnb's effects on the real estate market of the Greek island of Mikonos. Nonetheless, there is little research trying to characterize the market for $\mathrm{p} 2 \mathrm{p}$ accommodation and its impacts in an integral manner in island economies. We examine this in the case of Mallorca and Menorca.

\section{Methodology and data}

Our methodological approach is based on two case studies. Although its usage has been uneven over time (Tellis, 1997), case study research has a long tradition in the field of the social sciences and has achieved a certain degree of popularity in tourism research (Xiao \& Smith, 2006). This research method has been criticized for its inability to generalize and for its lack of scholarly rigour (Noor, 2008). However, the study of individual cases can be crucial for scientific development (Flyvbjerg, 2006). In this vein, our work first describes the defining features of the $\mathrm{p} 2 \mathrm{p}$ market in the geographical area of reference and, on that basis, an econometric analysis is used to quantify the impacts on the island economies under study.

The choice of the case is important (Ragin, 1992). The choice of Mallorca and Menorca is justified because both islands belong to the Balearic archipelago in the Mediterranean Sea, and their economy revolves around tourism to which more than $40 \%$ of 
their GDP and 30\% of employment can be attributed (Exceltur, 2014). Furthermore, these are two cases for which Airbnb penetration is particularly intense (Adamiak, Szyda, Dubownik, \& García-Álvarez, 2019). They are, therefore, two appropriate examples for the objectives that have been proposed and could be presented as exploratory cases (Yin, 1984).

The analysis of the $\mathrm{p} 2 \mathrm{p}$ market is hindered by the lack of official statistics and the reluctance of platforms to share their data. Nonetheless, some private initiatives such as Airdna (2019) or Insideairbnb (2019a) allow insights into the phenomenon by publishing data scraped from the advertisements posted on the Airbnb website. Their analysis can shed light on the characteristics of markets in different geographical areas. For Mallorca and Menorca, useful information exists on both the supply and demand sides to understand the elements of these markets.

The analysis of demand is more problematic due to the lack of information. While supply characteristics are readily available through the platform, the effective level of demand for each accommodation is unknown. However, the number of reviews - if available - can be used as a demand proxy. In the case of Airbnb, only the users who have booked a listing can leave a review. That is, the number of reviews defines a lower bound on the demand received by an accommodation. This method is partially flawed: first, it does not convey information on the length of the stay of guests; second, there is evidence that some experiences - the least satisfactory ones - tend to be underrepresented (Fradkin et al, 2015), which explains why accommodations have high average ratings (Zervas et al, 2015). Regardless of these limitations, the number of reviews is often used as an approximation to real listing occupancy (Lee et al, 2015; Quattrone et al, 2016); an example is the so-called San Francisco Model (Insideairbnb, 2019b).

In addition to data from Airbnb, we have gathered data from other statistical sources: the Statistics Institute of the Balearic Islands (Ibestat) and from Exceltur (2019), a non-profit organization constituted by the most relevant Spanish tourism companies.

\section{Descriptive analysis}

A descriptive analysis of the available information reveals the most important characteristics of the $\mathrm{p} 2 \mathrm{p}$ market for accommodation in Mallorca and Menorca: exponential growth, professionalized supply mainly consisting of entire homes, and geographically concentrated; and seasonal demand directed towards a small subset of accommodations.

\section{Exponential growth}

The exponential growth registered in the islands is also present in other territories, with different nuances and in varying scales. In Figure 1 we can observe that the first listings start to appear in the islands at the beginning of 2010. Up to 2018, more than 40,000 accommodations had been traded in Mallorca and more than 5,000 in Menorca. These figures measure the number of accommodations that were advertised in the platform at some point, without consideration of the time of permanence in it. 


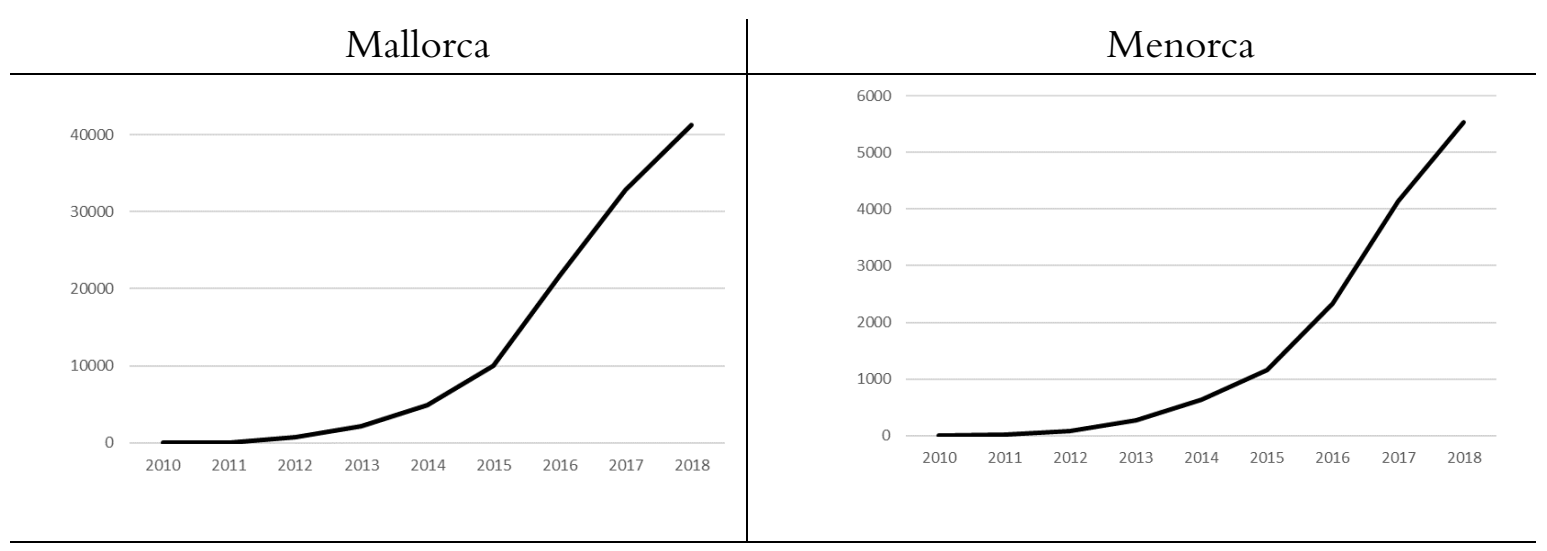

Figure 1: Total cumulative rental. Source: Compiled from Airdna (2019).

Professionalized supply of entire homes

Table 1 presents an analysis of accommodation supply. Generally speaking, Mallorca and Menorca's Airbnb accommodation supply have similar characteristics. First, more than 90\% of accommodations are entire homes. This percentage is appreciably higher than that registered elsewhere. For example, Ke (2017), performing a large-scale study on Airbnb supply in the world with more than 2 million listings, observes that the percentage of entire homes was on average never higher than $70 \%$. In most countries analyzed, entire homes outnumber private rooms. These findings support the thesis that, despite Airbnb's effort to present itself as an exponent of the sharing economy as opposed to profit-seeking hotels (Benítez-Aurioles, 2018b), in reality, it is closer to an online marketplace for commercial supply of short-term accommodation (Gyódi, 2019).

Table 1. Accommodation supply in Airbnb Mallorca (28 January 2019) and Menorca (30 January 2019). Source: Insideairbnb (2019).

\begin{tabular}{llrrrr}
\hline & \multicolumn{2}{c}{ Mallorca } & \multicolumn{2}{c}{ Menorca } \\
\hline \multirow{2}{*}{ Room Type } & Entire home & 13,428 & 91.6 & 2,105 & $\%$ \\
\cline { 2 - 6 } & Private room & 1,221 & 8.3 & 166 & 7.3 \\
\cline { 2 - 6 } & Shared room & 17 & 0.1 & 2 & 0.1 \\
\hline \multirow{2}{*}{ Host } & Professional & 11,514 & 78.5 & 1,512 & 66.5 \\
\cline { 2 - 6 } & Non- Professional & 3,152 & 21.5 & 761 & 33.5 \\
\hline \multicolumn{2}{l}{ Total Listings } & 14,666 & 100.0 & 2,273 & 100 \\
\hline \multicolumn{2}{l}{ Accommodates } & 90,803 & & 13,102 & \\
\hline
\end{tabular}

Additionally, hosts who offer more than one accommodation, known as 'professional hosts', also represent a high percentage of hosts: they supply $78.5 \%$ of total listings in Mallorca and $66.5 \%$ in Menorca. The distinction between professionals and non-professionals is relevant as long as there are differences in their performance. For example, it appears that professional hosts obtain higher income, higher occupancy rates, and a lower probability of abandoning the market than non-professional hosts (Li et al, 2016). Moreover, professional hosts seem to better adapt to demand fluctuations by applying dynamic pricing strategies (Gibbs, Guttentag, Gretzel, Yao, \& Morton, 2018). 


\section{Spatial concentration}

Listing density per $\mathrm{km}^{2}$ is higher in Mallorca than in Menorca. In the former there are 3.93 listings per $\mathrm{km}^{2}-26 \%$ more than in Menorca, with 3.11 listings per $\mathrm{km}^{2}$ (Figure 2), meaning that the $\mathrm{p} 2 \mathrm{p}$ market has a greater presence in the former island than in the latter. Yet, both cases display an unequal distribution across geography, as accommodation seems concentrated on the coast and in the urbanized core. In Mallorca, the bays of Pollença and Alcudia in the north, and of Palma in the south, concentrate just over $45 \%$ of total supply since they are some of the most sought-after destinations in the island. This is because of the beach attraction and because of the services provided. Instead, Menorca's accommodation is concentrated around its main population hub: Ciutadela de Mallorca, in the west, with also $45 \%$ of the listings.

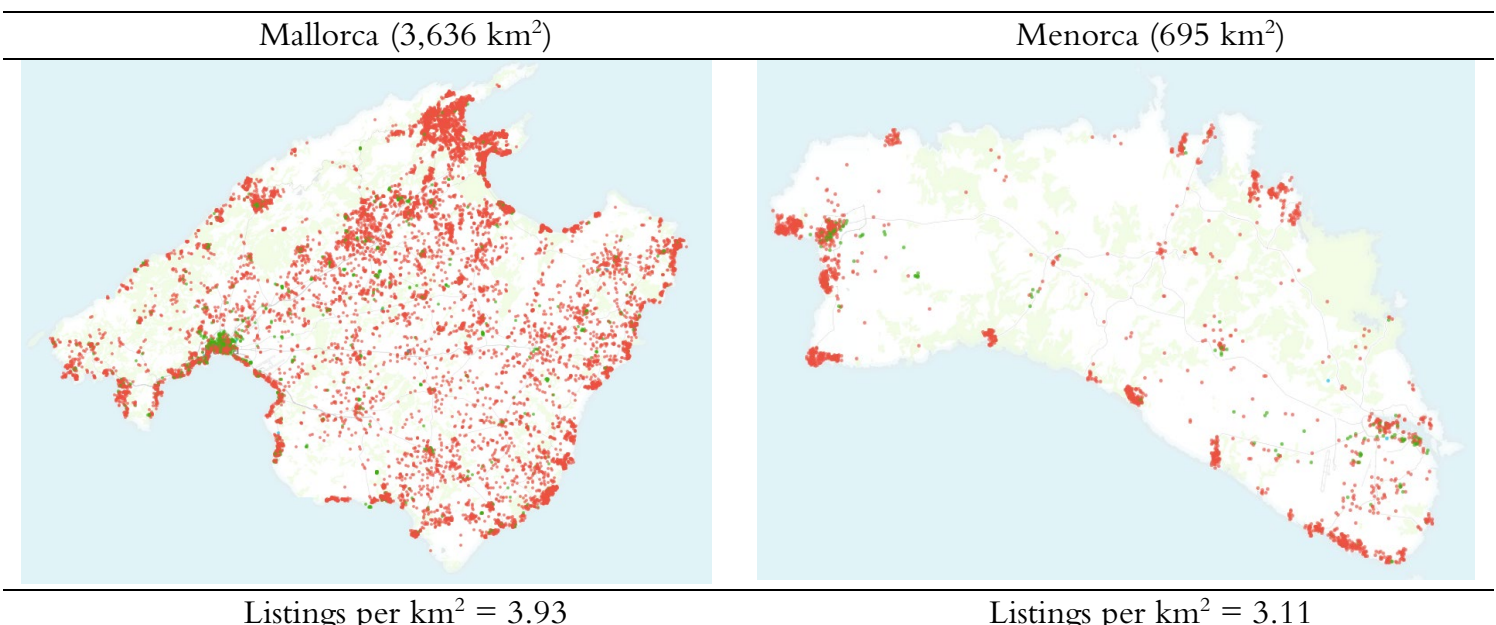

Figure 2: Spatial distribution of accommodation supply in Mallorca (28 January 2019) and Menorca (30 January 2019). Source: Insideairbnb (2019).

\section{Seasonality}

Figure 3 depicts the evolution in the number of reviews of listings that were active in early 2019 in each island. Besides the upward trend, what is most striking is the seasonal behaviour, which reaches its peaks in summer months and minima in winter. For example, the arrival of tourists in 2017 multiplied the population of Mallorca by 1.7 and that of Menorca by 2.4 (Ibestat, 2019). And, given the data presented here, the p2p market is unlikely to soften the seasonality of tourism demand in islands - at least, in the Balearics.

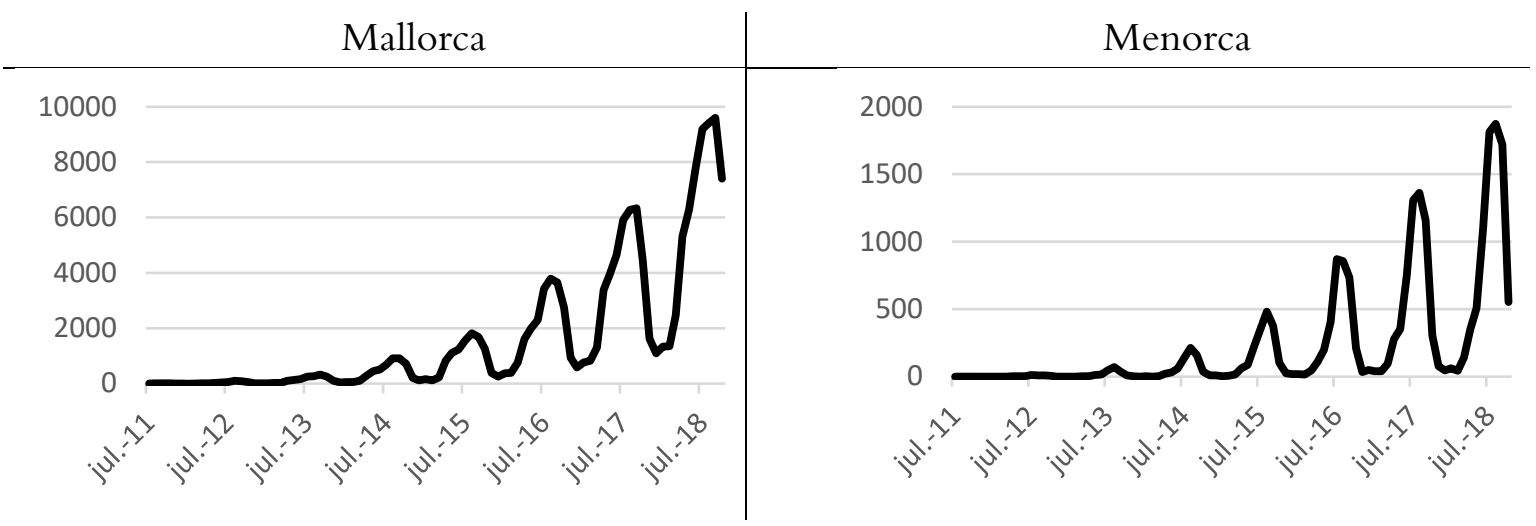

Figure 3: Evolution of the number of active listings in Mallorca (28 January 2019) and Menorca (30 January 2019). July 2011-October 2018. Source: Compiled from Insideairbnb (2019). 
Demand directed to a part of the supply

There is a concentration of demand in one part of the supply. In the case of Mallorca, such concentration is higher than in Menorca (Figure 4). The top 20\% of listings absorb $85 \%$ of reviews in Mallorca, and 73\% in Menorca. Meanwhile, the bottom $60 \%$ of accommodations only receives $2.6 \%$ of reviews in Mallorca, and $7.3 \%$ in Menorca.

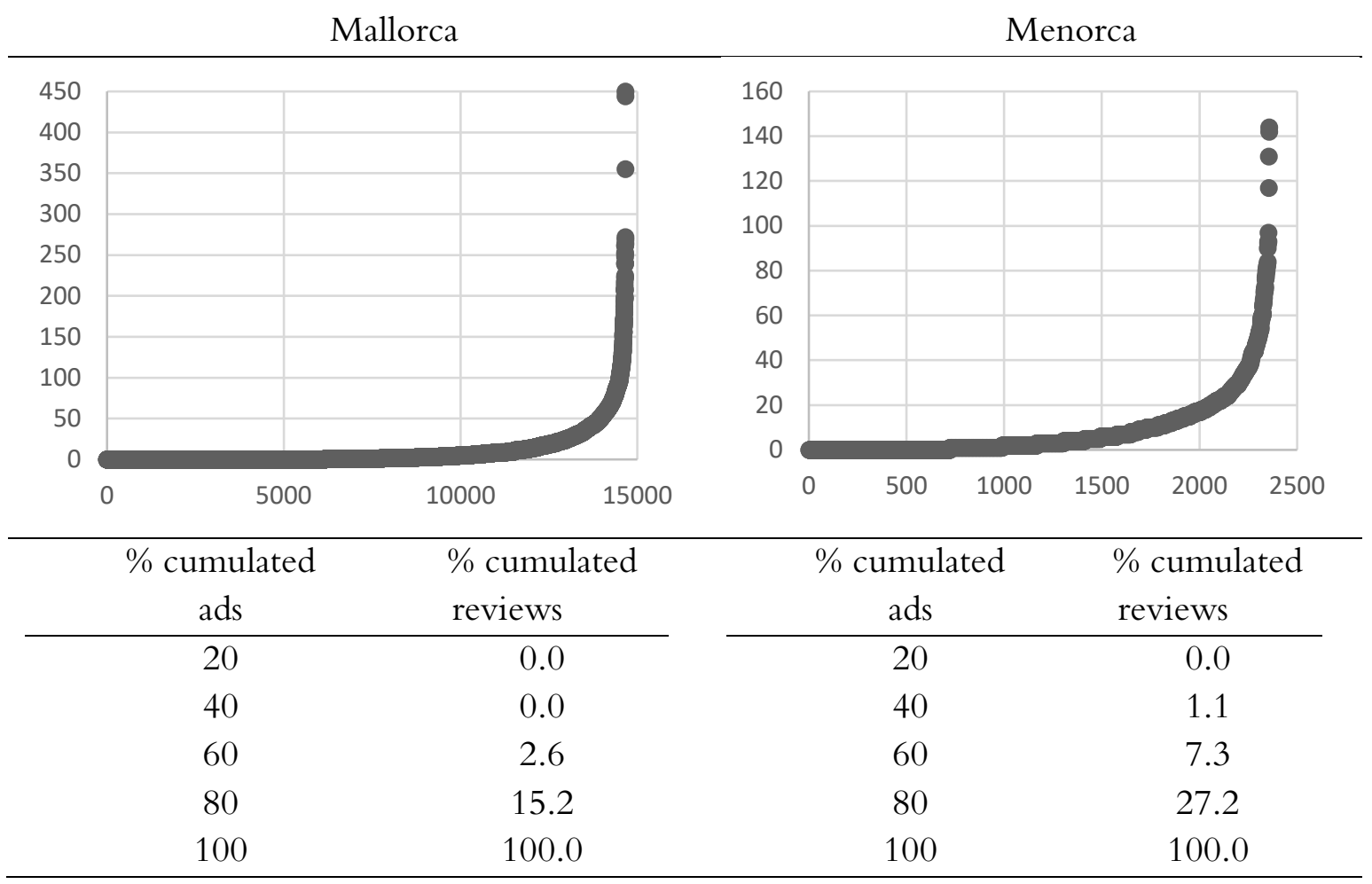

Figure 4: Number of reviews (ordinates) by ad (abscissae) in Mallorca (28 January 2019) and Menorca (30 January 2019). Source: Compiled from Insideairbnb (2019).

The resulting $\mathrm{J}$-shaped curve has long been observed in online rating systems $(\mathrm{Hu}$, Pavlou, \& Zhang, 2009). This occurs here with a concentration of reviews in a few accommodations. This distribution is compatible with the predictions of imitative behaviour models (Banerjee, 1992): facing an absence of objective indicators of quality, individuals follow in the steps of previous guests. This behaviour generates a cumulative dynamic in which the probability of booking increases with past bookings, while those who have never been booked are likely to stay in this situation.

According to Insideairbnb (2019b), one in three reviews on the island of Mallorca were left on a listing located in the capital, Palma; in Menorca, almost $60 \%$ of reviews so far in Menorca were on listings located in the most populated cities (Ciutadella and Mahón). The total number of reviews per $\mathrm{km}^{2}$ in Mallorca (38.4) is notably higher than that of Menorca (28.3). This difference suggests that the pressure exerted by tourists who resort to Airbnb accommodations is higher in the first of the two cases, and is yet another important statistic to understand the differences between the two islands. 


\section{Impacts}

Detailing the social impacts of the $\mathrm{p} 2 \mathrm{p}$ market might be particularly difficult in certain areas of Menorca or Mallorca (Yrigoy, 2018). This paper focuses on economic impacts, particularly its impact on hotel occupancy and its consequences on employment.

Empirical evidence on the impact on the conventional accommodation industry is inconclusive. Some studies show that the arrival of Airbnb has negatively affected hotels' performance (Xie \& Kwok, 2017; Zervas et al, 2017) while others do not find a statistically significant association (Blal, Singal, \& Templin, 2018; Heo et al, 2019). For employment, although studies have demonstrated that the arrival of Airbnb is positively related to employment growth (Mao et al, 2018), some have also pointed to a decreasing contribution as the options at the low-end of the market are substituted by Airbnb's supply (Fang et al, 2016). In contrast, Suciu (2016), in a study on 20 German cities, did not detect an effect of Airbnb's advent on hotel employment.

\section{Empirical strategy and results}

We approximate the impact of the $\mathrm{p} 2 \mathrm{p}$ market for tourist accommodation in islands on established accommodation, regressing the number of reviews on hotel occupancy at the municipal level, while controlling for the number of air passengers. The model equation is as follows:

$$
O c u_{i t}=\beta_{0}+\beta_{1} N R_{i t}+\operatorname{Pas}_{t}
$$

where $O c u$ is hotel occupancy as a percentage; $N R$ is the total number of reviews received by accommodations that were active towards the end of January 2019 in each municipality; and Pas the number of passengers that arrived by plane to each island (the subscripts $i$ and $t$ correspond to the municipality and the month and year, respectively). The data series covers the period from June 2011 to October 2018 (88 months); but information is not available at all points nor in every municipality, so the number of observations in the regressions is smaller than 88. In spite of these limitations, Table 2 reveals interesting results and highlights the effects of the development of the $\mathrm{p} 2 \mathrm{p}$ market for tourist accommodation in each island.

To value the impact on employment, panel data at the municipal level is used. The panel data comes from different sources, from the third quarter of 2011 to the third quarter of 2018. It features 53 towns in Mallorca and eight in Menorca. The following variables are measured at quarterly intervals: employment in the tourism industry (Employment); number of arriving air passengers (Passengers); and aggregate $\mathrm{p} 2 \mathrm{p}$ accommodation reviews in Airbnb properties (Reviews). The Employment and Passengers variables come from the sources previously mentioned, and the Reviews variable has been scrapped and compiled by InsideAirbnb.com. Tourism employment is used as the dependent variable. Reviews is the regressor of interest, included in a quadratic form (Reviews ${ }^{2}$ ) to evaluate the possibility of non-constant returns and of variation in the marginal effect of Airbnb reviews on tourism employment.

We use the number of air passengers as a control variable. It is to be expected that the number of tourists in general might increase in summer, and in certain dates and places (i.e., due to the celebration of an event of interest). In such situations, both tourist employment and Airbnb reviews would grow in parallel, but not in a directly related manner. Tourists to 
the Baleares Islands arrive mainly by air, since the islands are small in surface area (Mallorca is $3,640 \mathrm{~km}^{2}$ and Menorca is $696.7 \mathrm{~km}^{2}$ ). Therefore, arriving air passengers control for exogenous increases in $\mathrm{p} 2 \mathrm{p}$ accommodation reviews, so the variation coming from the interaction between the 'formal' tourism industry and that of the $\mathrm{p} 2 \mathrm{p}$ accommodation can be estimated.

Table 2: OLS regression on the percentage of hotel occupancy at the municipal level.

\begin{tabular}{|c|c|c|c|c|c|}
\hline & Reviews & Passengers & Constant & Adj R2 & $\mathrm{N}$ \\
\hline Mallorca & $-0.001 \star \star$ & $0.029 \star \star \star$ & $41.38 \star \star \star$ & 0.86 & 85 \\
\hline \multicolumn{6}{|l|}{ Alcudia } \\
\hline $3 \star$ & $-0.208 \star \star$ & $0.049 \star \star \star$ & 10.85 & 0.67 & 27 \\
\hline $4^{\star}$ & $-0.155^{\star \star \star}$ & $0.024 \star \star \star$ & $56.32 \star \star \star$ & 0.70 & 54 \\
\hline \multicolumn{6}{|l|}{ Calviá } \\
\hline $3 \star$ & $-0.023 \star \star$ & $0.018 \star \star \star$ & $58.95 \star \star \star$ & 0.65 & 39 \\
\hline $4 \star$ & $-0.032 \star \star$ & $0.033 \star \star \star$ & $33.88 \star \star \star$ & 0.87 & 65 \\
\hline $5 \star$ & $-0.043 \star \star \star$ & $0.029 \star \star \star$ & $31.95^{\star \star \star}$ & 0.61 & 27 \\
\hline \multicolumn{6}{|l|}{ Capdepera } \\
\hline $3 \star$ & -0.065 & $0.039 \star \star \star$ & 24.75 & 0.36 & 29 \\
\hline $4^{\star}$ & $-0.113 \star \star \star$ & $0.040 \star \star \star$ & $27.24 \star \star \star$ & 0.78 & 47 \\
\hline \multicolumn{6}{|l|}{ Llorenç } \\
\hline $3^{\star}$ & -0.059 & $0.022^{\star}$ & $55.69 \star \star$ & 0.14 & 23 \\
\hline $4^{\star}$ & $-0.093 \star \star$ & $0.031 \star \star \star \star$ & $40.17 \star \star \star$ & 0.64 & 40 \\
\hline \multicolumn{6}{|l|}{ Llucmajor } \\
\hline $3 \star$ & 0.159 & -0.021 & $90.08 \star \star \star$ & 0.17 & 10 \\
\hline \multicolumn{6}{|l|}{ Manacor } \\
\hline $3 \star$ & $-0.029 \star$ & $0.028 \star \star$ & $41.92 \star \star$ & 0.40 & 21 \\
\hline $4^{\star}$ & $-0.070 \star \star$ & $0.075 \star \star \star$ & -33.24 & 0.76 & 15 \\
\hline \multicolumn{6}{|l|}{ Margalida } \\
\hline $3 \star$ & $-0.069^{\star}$ & $0.036 \star \star$ & $35.62^{\star}$ & 0.40 & 19 \\
\hline $4 \star$ & $-0.060 \star \star \star$ & $0.040 \star \star \star$ & $28.01 \star \star \star$ & 0.79 & 39 \\
\hline \multicolumn{6}{|l|}{ Muro } \\
\hline $4^{\star}$ & $-0.101 \star \star \star$ & $0.032 \star \star \star$ & $40.45^{\star \star \star}$ & 0.79 & 46 \\
\hline \multicolumn{6}{|l|}{ Palma } \\
\hline $3 \star$ & -0.002 & $0.021 \star \star \star$ & $55.26 \star \star \star$ & 0.73 & 64 \\
\hline $4 \star$ & $-0.005^{\star \star \star}$ & $0.030 \star \star \star$ & $43.03 \star \star \star$ & 0.87 & 81 \\
\hline $5^{\star}$ & $-0.003^{\star}$ & $0.029 \star \star \star$ & 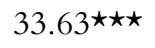 & 0.86 & 65 \\
\hline \multicolumn{6}{|l|}{ Santanyi } \\
\hline $3 \star$ & -0.012 & $0.026^{\star}$ & $46.54 \star \star$ & 0.17 & 24 \\
\hline $4^{\star}$ & $-0.044 \star \star \star$ & $0.033^{\star \star \star}$ & $42.13 \star \star \star$ & 0.77 & 42 \\
\hline Menorca & 0.002 & $0.197 \star \star \star$ & $35.95^{\star \star \star}$ & 0.79 & 85 \\
\hline \multicolumn{6}{|l|}{ Ciutadella } \\
\hline Total & -0.004 & 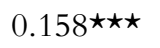 & $47.71 \star \star \star$ & 0.63 & 58 \\
\hline $3 \star$ & 0.003 & 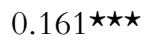 & $43.53 \star \star \star$ & 0.51 & 30 \\
\hline $4^{\star}$ & -0.007 & 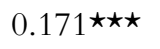 & $47.57 \star \star \star$ & 0.66 & 34 \\
\hline
\end{tabular}

Empirically, we run the following fixed effects linear equation:

$$
\log \text { Employment }_{i t}=\beta_{0}+\beta_{1} \text { Reviews }_{i t}+\beta_{2} \text { Reviews }_{i t}^{2}+\beta_{3} \text { Passengers }+\gamma_{i}+\epsilon_{i t}
$$

where $i$ is the town, $t$ is the year-quarter date, and $\gamma_{i}$ is a series of fixed town effects that are included to capture unobserved heterogeneity across them. $\epsilon_{i t}$ is a random error term. 
Because of the Wald test being significant for both islands $\left(\chi_{53}^{2}=2.3 \mathrm{e}+05\right.$, p-value $<0.0000$ for Mallorca; $\chi_{53}^{2}=3.9 \mathrm{e}+05$, p-value $<0.0000$ for Menorca), we use cluster-robust standard errors in the estimation to control for groupwise heteroscedasticity. Estimation results are presented in Table 3.

Table 3: Effect of Airbnb on employment in the tourism industry.

\begin{tabular}{lrr}
\hline & Mallorca & Menorca \\
\hline Reviews & $0.0003556 \star \star \star$ & 0.0002519 \\
Reviews ${ }^{2}$ & $-0.0000000444 \star \star \star$ & $-0.000000127 \star$ \\
Passengers & $0.000000123 \star \star \star$ & $0.00000146 \star \star \star$ \\
Intercept & $5.269114 \star \star \star$ & $5.600461 \star \star \star$ \\
R-square & 0.0537 & 0.1446 \\
F test & 284.67 & 376.38 \\
Number of obs. & (Prob $>$ F $=0.0000)$ & (Prob $>\mathrm{F}=0.0000)$ \\
Number of groups & 1,537 & 232 \\
\hline$\star \star \star \mathrm{p}<0.01,{ }^{\star}{ }_{\mathrm{p}}<0.05,{ }^{\star} \mathrm{p}<0.1$ & 53 & 8 \\
\hline
\end{tabular}

\section{Discussion}

In Mallorca, an inverse relationship between the number of reviews and the degree of occupancy in hotels is appreciable. This pattern is repeated in each municipality and for the different hotel categories. Almost all coefficients are negative and statistically significant. Likewise, it is noteworthy that in multiple cases, the coefficient increases with hotel category. These results challenge the idea that lower-category hotels are more affected by Airbnb's expansion. By comparison, in Menorca, there is no statistically significant relationship between the number of reviews and hotel occupancy. Perhaps, in this case, the $\mathrm{p} 2 \mathrm{p}$ market may have not developed beyond the threshold needed to affect hotel occupancy; although this could also raise the hypothesis that the supply in each of these markets - traditional and $\mathrm{p} 2 \mathrm{p}$ - are not necessarily substitutes, as certain authors suggest (Heo et al, 2017; Johnson \& Neuhofer, 2017).

The number of reviews is linearly associated with tourism employment in a positive manner: the coefficient on Reviews is 0.0003556 in Mallorca ( $\mathrm{p}$-value $=0.000$ ) and, albeit non-significantly, 0.0002519 in Menorca ( $p$-value $=0.193$ ). The quadratic coefficient is negative for both islands: $-2.80 \mathrm{e}-07$ for Mallorca ( $\mathrm{p}$-value $=0.000)$ and $-1.27 \mathrm{e}-07$ for Menorca $(\mathrm{p}$-value $=0.086)$. This means that, although the positive association fades away as the values get larger, there exists an initial stage where the relationship is positive and both Airbnb reviews and tourism employment grow simultaneously, indicating that an interaction between the traditional and informal markets working in either or both directions is complementary.

One might be concerned about the possible correlation between air passengers and Airbnb's competitiveness. This would mean that, for example, both the number of reviews and the air passenger arrivals in a given period might be high not because of external reasons that affect the tourism industry as well as the $\mathrm{p} 2 \mathrm{p}$ accommodation market, but because the $\mathrm{p} 2 \mathrm{p}$ market attracts more foreign tourists irrespective of the performance of the traditional industry.

For a constant number of air passengers, we seek to determine how the state of tourism employment and of $\mathrm{p} 2 \mathrm{p}$ accommodation reviews varies. If the number of total air passengers 
grow, the relationship between both industries is lost and attributed to air passengers (whose coefficient would be downwardly estimated), while the coefficient on reviews would be biased downwards (if complementarity is absent) or upward (if competition is absent). Therefore, the same models are estimated without the term $\beta_{3}$ Passengers. Similar coefficients are obtained for the main explanatory variable albeit the coefficients are larger: this increase probably comes from the positive correlation due to external factors such as the season, but also indicates that competition effects are absent or not large.

Another robustness check that is performed is the use of rolling averages for the variables Reviews and Reviews ${ }^{2}$. The coefficients have the same signs as previously estimated but are larger in magnitude $\left(\hat{\beta}_{1}=0.0004586(\mathrm{p}<0.000)\right.$ and $\hat{\beta}_{2}=-6.57 \mathrm{e}-08(\mathrm{p}<0.000)$ for Mallorca; $\hat{\beta}_{1}=0.0007987(\mathrm{p}=0.040)$ and $\hat{\beta}_{2}=-3.19 \mathrm{e}-07(\mathrm{p}=0.110)$ for Menorca), meaning that even the smoothed data has these positive effects from $\mathrm{p} 2 \mathrm{p}$ accommodation visits. These effects would benefit the tourism industry as a whole, due to the greater affordability of this type of housing.

\section{Conclusions and implications}

The exponential growth experienced in the $\mathrm{p} 2 \mathrm{p}$ market for tourist accommodation is of special interest to islands where tourism represents a primary source of income. Taking the cases of Mallorca and Menorca, the analysis reveals that some of the characteristics of this market are intense in the islands. Thus, more than $90 \%$ of accommodations offered on the Airbnb platform constitute entire homes; the majority of accommodation belong to professional hosts (hosts that own more than one Airbnb listing); and demand is concentrated in a reduced part of supply.

The concentration of $\mathrm{p} 2 \mathrm{p}$ accommodation market supply in geography and in time is remarkable. Given that the supply stems from already built homes, the urban structure of islands preconditions its spatial distribution. Thus, the limitations to the growth of the supply of accommodation in the islands can be overcome using existing private homes in the urban centres and on the coast. On the demand side, a clear seasonal pattern can be seen which accentuates the pressure of tourism in certain times of the year and results in adverse external effects on the resident population.

Regarding the impact of the $\mathrm{p} 2 \mathrm{p}$ market on the conventional tourism industry and its employment in islands, the results suggest the existence of a threshold above which the effects begin to be appreciable. In the case of Mallorca, with high market penetration, as the number of tourists staying in private homes increases, hotel occupancy decreases, independent of hotel category; while the level of employment in the tourism sector increases, although its marginal effect decreases as the market expands. Empirical evidence points to the expansion of the $\mathrm{p} 2 \mathrm{p}$ market being detrimental to hotels, but benefiting employment. Conversely, the lower development of this market in Menorca may explain why these claims are not supported in this island.

The results have immediate implications both for tourist companies that are established in the islands and for policymakers. There is a threshold, apparently exceeded in Mallorca but not in Menorca, after which Airbnb penetration starts to affect the economic performance of hotels, at least in terms of occupancy. Under these conditions, established conventional accommodation businesses in the islands may have to devise strategies to retain and attract 
tourists. If they cannot compete in price with private housing suppliers, perhaps they should consider a differentiated service provision in the management of their establishments. On the contrary, the analysis suggests that Airbnb expansion is correlated with job creation, which is compatible with benefits in tourism-related firms that do not provide accommodation.

From the public point of view, the issue complicates the debate on the adequacy of strengthening tourism as basis for the development of islands. In this sense, some of the traditional problems of tourism in these territories, such as seasonality or the pressure on environmental resources, acquire a new dimension when tourist activity increases in urban zones, which can cause tensions with residents and other undesirable effects on the housing market. Still, there are also benefits for the local population who rent their house or are employed thanks to the arrival of new tourists. The art of maximizing residents' welfare is the task of policymakers.

A limitation of this research is related to the lack of data, methodology, and empirical strategy used. In particular, there was not a direct estimation of Airbnb demand but an approximation through reviews received by the listings that were active in a particular point in time. The results obtained for the cases of Mallorca and Menorca have their idiosyncrasies, and therefore are not generalizable to all other islands. Finally, using aggregated results might hide important differences both across geography and between firms. These limitations can actually be viewed as opportunities for future research. For instance, a database with individualized information for hotels registering not only occupancy but other key variables of their economic performance (such as the average daily rate (ADR)) would allow a replication and extension of this work on other islands. Along these lines, the extent to which the islands' institutional framework, access facilities, size, and natural resources condition the impact of the development of the $\mathrm{p} 2 \mathrm{p}$ market for tourist accommodation could be considered.

\section{References}

Adamiak, C., Szyda, B., Dubownik, A., \& García-Álvarez, D. (2019). Airbnb offer in Spain: Spatial analysis of the pattern and determinants of its distribution. ISPRS International Journal of Geo-Information, 8(3), 155. https://doi.org/10.3390/ijgi8030155

Airbnb (2019). Fast facts. Retrieved from https://press.airbnb.com/fast-facts/

Airdna (2019). Vacation rental data to set you apart. Insights to keep you ahead. Retrieved from https://www.airdna.co/

Archer, B. (1995). Importance of tourism for the economy of Bermuda. Annals of Tourism Research, 22(4), 918-930. https://doi.org/10.1016/0160-7383(95)00018-1

Ayres, R. (2000). Tourism as a passport to development in small states: Reflections on Cyprus. International Journal of Social Economics, 27(2), 114-133. https://doi.org/10.1108/03068290010308992

Banerjee, A.V. (1992). A simple model of herd behavior. The Quarterly Journal of Economics, 107(3), 797-817. https://doi.org/10.2307/2118364

Barron, K., Kung, E., \& Proserpio, D. (2018). The sharing economy and housing affordability: Evidence from Airbnb. Retrieved from https://ssrn.com/abstract $=3006832$

Baum, T., \& Lundtorp, S. (Eds.) (2001). Seasonality in tourism. Oxford: Elsevier. 
Belarmino, A., \& Koh, Y. (2020). A critical review of research regarding peer-to-peer accommodations. International Journal of Hospitality Management, 84, 102315. https://doi.org/10.1016/j.ijhm.2019.05.011

Benítez-Aurioles, B. (2018a). Why are flexible booking policies priced negatively? Tourism Management, 67, 312-325. https://doi.org/10.1016/j.tourman.2018.02.008

Benítez-Aurioles, B. (2018b). Estrategias de comunicación: Airbnb versus hoteles/Communication strategies: Airbnb versus hotels. Revista Internacional de Relaciones Públicas, 8(16), 47-66. http://dx.doi.org/10.5783/RIRP-16-2018-04-47$\underline{66}$

Blal, I., Singal, M., \& Templin, J. (2018). Airbnb's effect on hotel sales growth. International Journal of Hospitality Management, 73, 85-92. https://doi.org/10.1016/j.ijhm.2018.02.006

Bojanic, D.C., \& Lo, M. (2016). A comparison of the moderating effect of tourism reliance on the economic development for islands and other countries. Tourism Management, 53, 207-214. https://doi.org/10.1016/j.tourman.2015.10.006

Brida, J.G., Cortes-Jimenez, I., \& Pulina, M. (2016). Has the tourism-led growth hypothesis been validated? A literature review. Current Issues in Tourism, 19(5), 394-430. https://doi.org/10.1080/13683500.2013.868414

Camilleri, J., \& Neuhofer, B. (2017). Value co-creation and co-destruction in the Airbnb sharing economy. International Journal of Contemporary Hospitality Management, 29(9), 2322-2340. https://doi.org/10.1108/IJCHM-09-2016-0492

Campbell, M., McNair, H., Mackay, M., \& Perkins, H.C. (2019). Disrupting the regional housing market: Airbnb in New Zealand. Regional Studies, Regional Science, 6(1), 139142. https://doi.org/10.1080/21681376.2019.1588156

Chen, R.J. (2006). Islands in Europe: Development of an island tourism multi-dimensional model (ITMDM). Sustainable Development, 14(2), 104114. https://doi.org/10.1002/sd.302

Dann, D., Teubner, T., \& Weinhardt, C. (2019). Poster child and guinea pig-insights from a structured literature review on Airbnb. International Journal of Contemporary Hospitality Management, 31(1), 427-473. https://doi.org/10.1108/IJCHM-03-2018-0186

Dolnicar, S. (2019). A review of research into paid online peer-to-peer accommodation: Launching the Annals of Tourism Research curated collection on peer-to-peer accommodation. Annals of Tourism Research, 75, 248-264. https://doi.org/10.1016/j.annals.2019.02.003

Donatos, G., \& Zairis, P. (1991). Seasonality of foreign tourism in the Greek island of Crete. Annals of Tourism Research, 18(3), 515-519. https://doi.org/10.1016/01607383(91)90060-O

Durbarry, R. (2002). The economic contribution of tourism in Mauritius. Annals of Tourism Research, 29(3), 862-865. https://doi.org/10.1016/S0160-7383(02)00008-7

Durbarry, R. (2004). Tourism and economic growth: the case of Mauritius. Tourism Economics, 10(4), 389-401. https://doi.org/10.5367/0000000042430962

Dwyer, L., \& Forsyth, P. (1993). Assessing the benefits and costs of inbound tourism. Annals of Tourism Research, 20(4), 751-768. https://doi.org/10.1016/0160-7383(93)90095-K 
Edelman B., Luca, M., \& Svirsky, D. (2017). Racial discrimination in the sharing economy: evidence from a field experiment. American Economic Journal: Applied Economics, 9(2), 1-22. https://doi.org/10.1257/app.20160213

Einav, L., Farronato, C., \& Levin, J. (2016). Peer-to-peer markets. Annual Review of Economics, 8, 615-635. https://doi.org/10.1146/annurev-economics-080315-015334

Eugenio-Martin, J.L., Cazorla-Artiles, J.M., \& González-Martel, C. (2019). On the determinants of Airbnb location and its spatial distribution. Tourism Economics/ https://doi.org/10.1177/1354816618825415

Exceltur (2014). Impactur 2014. Estudio del impacto económico del turismo sobre la economía y el empleo de las Illes Balears. https://www.exceltur.org/wpcontent/uploads/2015/10/IMPACTUR-Baleares-2014-informe-completo.pdf

Exceltur (2019). Barómetro rentabilidad destinos turísticos. https://www.exceltur.org/

Fang, B., Ye, Q., \& Law, R. (2016). Effect of sharing economy on tourism industry employment. Annals of Tourism Research, 57(3), 264-267. https://doi.org/10.1016/j.annals.2015.11.018

Figini, P., \& Vici, L. (2010). Tourism and growth in a cross section of countries. Tourism Economics, 16(4), 789-805. https://doi.org/10.5367/te.2010.0009

Flyvbjerg, B. (2006). Five misunderstandings about case-study research. Qualitative Inquiry, 12(2), 219-245. https://doi.org/10.1177/1077800405284363

Fotiou, S., Buhalis, D., \& Vereczi, G. (2002). Sustainable development of ecotourism in small islands developing states (SIDS) and other small islands. Tourism and Hospitality Research, 4(1), 79-88.

Fradkin, A., Grewal, E., Holtz, D., \& Pearson, M. (2015). Bias and reciprocity in online reviews: Evidence from field experiments on Airbnb. Proceedings of the 18th ACM Conference on Economics and Computation. New York, ACM. https://doi.org/10.1145/2764468.2764528

Ghina, F. (2003). Sustainable development in small island developing states. Environment, Development and Sustainability, 5(1-2), 139-165. https://doi.org/10.1023/A:1025300804112

Gibbs, C., Guttentag, D., Gretzel, U., Yao, L., \& Morton, J. (2018). Use of dynamic pricing strategies by Airbnb hosts. International Journal of Contemporary Hospitality Management, 30(1), 2-20. https://doi.org/10.1108/IJCHM-09-2016-0540

Grimmer, L., Vorobjovas-Pinta, O., \& Massey, M. (2019). Regulating, then deregulating Airbnb: The unique case of Tasmania (Australia). Annals of Tourism Research, 75, 204307. https://doi.org/10.1016/j.annals.2019.01.012

Guttentag, D. (2015). Airbnb: disruptive innovation and the rise of an informal tourism accommodation sector. Current Issues in Tourism, 18(12), 1192-1217. https://doi.org/10.1080/13683500.2013.827159

Guttentag, D. (2019). Progress on Airbnb: A literature review. Journal of Hospitality and Tourism Technolog $\gamma$. https://doi.org/10.1108/JHTT-08-2018-0075

Gyódi, K. (2019). Airbnb in European cities: Business as usual or true sharing economy? Journal of Cleaner Production. https://doi.org/10.1016/j.jclepro.2019.02.221 
Hartmans, A. (2017). Airbnb now has more listings worldwide than the top five hotel brands combined. Business Insider. Retrieved from https://www.businessinsider.com/airbnb-total-worldwide-listings-2017-8? IR =T

Heo, C.Y., Blal, I., \& Choi, M. (2019). What is happening in Paris? Airbnb, hotels, and the Parisian market: A case study, Tourism Management, 70, 78-88. https://doi.org/10.1016/j.tourman.2018.04.003

Horn, K., \& Merante, M. (2018). Is home sharing driving up rents? Evidence from Airbnb in Boston. Journal of Housing Economics, 38, 14-24. https://doi.org/10.1016/j.jhe.2017.08.002

Hu, N., Pavlou, P.A., \& Zhang, J. (2009). Overcoming the J-shaped distribution of product reviews. Communications of the ACM, 52(10), 144-147. https://doi.org/10.1145/1562764.1562800

Ibestat (2019). Estudios demográficos. Retrieved from https://www.caib.es/ibestat/estadistiques/poblacio/estudis-demografics/867ce696933c-4f66-9243-56c3712f4d2f

Insideairbnb (2019a). How is Airbnb really being used in and affecting the neighborhoods of your city? Retrieved from http://insideairbnb.com/

Insideairbnb (2019b). About inside Airbnb. Retrieved from http://insideairbnb.com/about.html

Jackman, M. (2012). Revisiting the tourism-led growth hypothesis for Barbados: A disaggregated market approach. Regional and Sectoral Economic Studies, 12(2), 15-26. Retrieved from https://EconPapers.repec.org/RePEc:eaa:eerese:v:12:y2012:i:2 3

Johnson, A.G., \& Neuhofer, B. (2017). Airbnb-an exploration of value co-creation experiences in Jamaica. International Journal of Contemporary Hospitality Management, 29(9), 2361-2376. https://doi.org/10.1108/IJCHM-08-2016-0482

Kakar, V., Franco, J., Voelz, J., \& Wu, J. (2016). The visible host: Does race guide Airbnb rental rates in San Francisco?. Journal of Housing Economics, 40, 25-40. https://doi.org/10.1016/j.jhe.2017.08.001

Karlsson, L., \& Dolnicar, S. (2016). Someone's been sleeping in my bed. Annals of Tourism Research, 58, 156-170. https://doi.org/10.1016/j.annals.2016.02.006

Katircioglu, S. (2009). Testing the tourism-led growth hypothesis: The case of Malta. Acta Oeconomica, 59(3), 331-343. https://doi.org/10.1556/AOecon.59.2009.3.4

Katircioglu, S. (2010). Research note: Testing the tourism-led growth hypothesis for Singapore-an empirical investigation from bounds test to cointegration and Granger causality tests. Tourism Economics, 16(4), 1095-1101. https://doi.org/10.5367/te.2010.0012

Ke, Q. (2017). Sharing means renting? An entire-marketplace analysis of Airbnb. In Proceedings of the 2017 ACM on web science conference (pp. 131-139). ACM. https://doi.org/10.1145/3091478.3091504

Khan, H., Seng, C.F., \& Cheong, W.K. (1990). The social impact of tourism on Singapore. Service Industries Journal, 10(3), 541-548. https://doi.org/10.1080/02642069000000057

Kim, H.J., Chen, M.H., \& Jang, S. (2006). Tourism expansion and economic development: The case of Taiwan. Tourism Management, 27(5), 925-933. https://doi.org/10.1016/j.tourman.2005.05.011 
Kokkranikal, J., McLellan, R., \& Baum, T. (2003). Island tourism and sustainability: A case study of the Lakshadweep Islands. Journal of Sustainable Tourism, 11(5), 426-447. https://doi.org/10.1080/09669580308667214

Lee, C.C., \& Chang, C.P. (2008). Tourism development and economic growth: A closer look at panels. Tourism Management, 29(1), 180-192. https://doi.org/10.1016/j.tourman.2007.02.013

Lee, D., Hyun, W., Ryu J., Lee W., Rhee W., \& Suh B. (2015). An analysis of social features associated with room sales of Airbnb, Proceedings of the 18th 33 ACM Conference on Computer Supported Cooperative Work \& Social Computing. ACM, Vancouver. https://doi.org/10.1145/2685553.2699011

Li, J., Moreno, A., \& Zhang, D. (2016). Pros vs joes: Agent pricing behavior in the sharing $\begin{array}{lllll}\text { economy. Ross School of } & \text { Business }\end{array}$ http://dx.doi.org/10.2139/ssrn.2708279

Malazizi, N., Alipour, H., \& Olya, H. (2018). Risk perceptions of Airbnb hosts: Evidence $\begin{array}{lll}\text { from } & \text { a } & \text { Mediterranean island. Sustainability, 10(5), }\end{array}$ https://doi.org/10.3390/su10051349

Mao, Y., Tian, X., \& Ye, K. (2018). The real effects of sharing economy: Evidence from Airbnb. Cornell University, School of Hotel Administration. https://scholarship.sha.cornell.edu/workingpapers/49

Martín Martín, J., Rodriguez Martín, J., Zermeño Mejía, K., \& Salinas Fernández, J. (2018). Effects of vacation rental websites on the concentration of tourists-potential environmental impacts. An application to the Balearic Islands in Spain. International Journal of Environmental Research and Public Health, 15(2), 347. https://doi.org/10.3390/ijerph15020347

Milne, S. (1992). Tourism and development in South Pacific microstates. Annals of Tourism Research, 19(2), 191-212. https://doi.org/10.1016/0160-7383(92)90077-3

Narayan, P.K., Narayan, S., Prasad, A., \& Prasad, B.C. (2010). Tourism and economic growth: a panel data analysis for Pacific Island countries. Tourism Economics, 16(1), 169-183. https://doi.org/10.5367/000000010790872006

Noor, K.B.M. (2008). Case study: A strategic research methodology. American Journal of Applied Sciences, 5(11), 1602-1604. https://doi.org/10.3844/ajassp.2008.1602.1604

Oskam, J., \& Boswijk, A. (2016). Airbnb: the future of networked hospitality businesses. Journal of Tourism Futures, 2(1), 22-42. https://doi.org/10.1108/JTF-11$\underline{2015-0048}$

Parra-López, E., \& Martínez-González, J.A. (2018). Tourism research on island destinations: a review. Tourism Review, 73(2), 133-155. https://doi.org/10.1108/TR-03-2017$\underline{0039}$

Parrilla, J.C., Font, A.R., \& Nadal, J.R. (2007). Tourism and long-term growth a Spanish perspective. Annals of Tourism Research, 34(3), $\quad$ 709-726. https://doi.org/10.1016/j.annals.2007.02.003

Podhorodecka, K. (2018). Tourism economies and islands' resilience to the global financial crisis. Island Studies Journal, 13(2), 163-184. https://doi.org/10.24043/isj.43

Pratt, S. (2015). The economic impact of tourism in SIDS. Annals of Tourism Research, 52, 148-160. https://doi.org/10.1016/j.annals.2015.03.005 
Quattrone, G., Proserpio, D., Quercia, D., Capra, L., \& Musolesi, M. (2016). Who benefits from the sharing economy of Airbnb? Proceedings of the 25th international conference on world wide web. International World Wide Web Conferences Steering Committee. https://doi.org/10.1145/2872427.2874815

Ragin, C. (1992). 'Casing' and the process of social inquiry. In C.C. Ragin \& H.S. Becker (Eds.). What is a case? Exploring the foundations of social inquiry (pp. 217-226). Cambridge: Cambridge University Press.

Scheyvens, R., \& Momsen, J.H. (2008). Tourism and poverty reduction: Issues for small island states. Tourism Geographies, 10(1), 22-41. https://doi.org/10.1080/14616680701825115

Seetanah, B. (2011). Assessing the dynamic economic impact of tourism for island economies. Annals of Tourism Research, 38(1), 291-308. https://doi.org/10.1016/j.annals.2010.08.009

Shareef, R., \& McAleer, M. (2005). Modelling international tourism demand and volatility in small island tourism economies. International Journal of Tourism Research, 7(6), 313333. https://doi.org/10.1002/jtr.538

Sharpley, R. (2003). Tourism, modernization and development on the island of Cyprus: Challenges and policy responses. Journal of Sustainable Tourism, 11(2-3), 246-265. https://doi.org/10.1080/09669580308667205

So, K.K.F., Oh, H., \& Min, S. (2018). Motivations and constraints of Airbnb consumers: Findings from a mixed-methods approach. Tourism Management, 67, 224-236. https://doi.org/10.1016/j.tourman.2018.01.009

Suciu, A.M. (2016). The impact of Airbnb on local labour markets in the hotel industry in Germany. https://doi.org/10.2139/ssrn.2874861

Teelucksingh, S.S., \& Watson, P.K. (2013). Linking tourism flows and biological biodiversity in Small Island Developing States (SIDS): Evidence from panel data. Environment and Development Economics, 18(4), 392-404. https://doi.org/10.1017/S1355770X13000120

Tellis, W.M. (1997). Introduction to case study. The qualitative report, 3(2), 1-14. Retrieved from https://nsuworks.nova.edu/tqr/vol3/iss $2 / 4$

Wang, D., \& Nicolau, J.L. (2017). Price determinants of sharing economy based accommodation rental: A study of listings from 33 cities on Airbnb.com. International Journal of Hospitality Management, 62, 120-131. https://doi.org/10.1016/j.ijhm.2016.12.007

Wilkinson, P.F. (1989). Strategies for tourism in island microstates. Annals of Tourism Research, 16(2), 153-177. https://doi.org/10.1016/0160-7383(89)90065-0

Xiao, H., \& Smith, S.L. (2006). Case studies in tourism research: A state-of-the-art analysis. Tourism Management, 27(5), 738-749. https://doi.org/10.1016/j.tourman.2005.11.002

Xie, K.L., \& Kwok, L. (2017). The effects of Airbnb's price positioning on hotel performance. International Journal of Hospitality Management, 67, 174-184. https://doi.org/10.1016/j.ijhm.2017.08.011

Xifilidou, A., Mangina, K., \& Karanikolas, N. (2018). 'Sharing' the Mykonian summer: The case of AirBnB. RELAND: International Journal of Real Estate \& Land Planning, 1, 268275. Retrieved from http://ejournals.lib.auth.gr/reland/article/view/6482 
Yin, R.K. (1984). Case study research: Design and methods. Beverly Hills: Sage Publications.

Yrigoy, I. (2018). Rent gap reloaded: Airbnb and the shift from residential to touristic rental housing in the Palma Old Quarter in Mallorca, Spain. Urban Studies, https://doi.org/10.1177/0042098018803261.

Zervas, G., Proserpio, D., \& Byers, J. (2015). A first look at online reputation on Airbnb, where every stay is above average (January 28, 2015). Retrieved from https://collaborativeeconomy.com/wp/wp-content/uploads/2015/04/Byers-D.Proserpio-D.-Zervas-G.2015.A-First-Look-at-Online-Reputation-on-AirbnbWhere-Every-Stay-is-Above-Average.Boston-University.pdf.

Zervas, G., Proserpio, D., \& Byers, J. (2017). The rise of the sharing economy: Estimating the impact of Airbnb on the hotel industry. Journal of Marketing Research 54(5), 687705. https://doi.org/10.1509/jmr.15.0204 